\title{
INVESTMENT ENVIRONMENT AND DEVELOPMENT POLICY OF ENTERPRISES IN SERBIA
}

\author{
Dušan Aničić ${ }^{1}$, Olgica Nestorović ${ }^{2}$, Danijela Andjelković3 \\ ${ }^{1,3}$ University Union - Nikola Tesla, Faculty of Economics and Finance, Belgrade, Serbia \\ ${ }^{2}$ International University Travnik, Faculty of Economics, Bosnia and Hercegovina \\ anicic.dusan@yahoo.com, olgica.n@yahoo.com, andjelkodani@yahoo.com
}

\section{Original Scientific Paper 10.5937/jouproman9-30925}

\begin{abstract}
Despite significant growth rates of over 4\% in 2018 and 2019, the Serbian economy still lags far behind developed countries in terms of productivity, competitiveness and other business performance indicators. In the future, the main drivers of economic growth must be investments and exports, and consumption must grow more slowly relative to GDP. Opportunities for increasing GDP exist, and one of them is the increase of public investments that have a positive effect on the growth of the rest of the economy. Empirical research has shown that countries that have higher domestic savings have higher investments and faster economic growth. Also, the development of the country must not be based only on the growth of FDI, because, in addition to the positive ones, they also have great negative effects on the growth and long-term sustainable development of the domestic economy.
\end{abstract}

Key words: investments, enterprise, development policy, Serbia

\section{Introduction}

Investments are a key direct factor in economic growth because the level and efficiency of investments reflect the quality of economic policy and institutions.Investments also affect other factors of economic growth, such as technical progress and employment.The impact of investments on economic growth depends on numerous factors, such as the macroeconomic and institutional environment, the openness of economy, the intensity of competition, etc. Enterprise's investment policy is based on analysis of the market environment, the opportunities and threats it carries, as well as a realistic view of the internal opportunities and weaknesses that are immanent to each enterprise.It is indisputable that the economic policy of Serbia must notice the existing weaknesses in terms of encouraging investments in all economic sectors, especially those from the real sector, such as agriculture, processing industry and others.

\section{Macroeconomic indicators and investment environment in Serbia}

In Serbia, domestic investments (both public and private) are very low, while foreign direct investments (FDI) are relatively high. The main causes of low domestic private investments are unfavorable general business conditions and low domestic savings. Public investment is low due to state inefficiency as well as the fact that current consumption is preferred to investment. On the other hand, FDI is high due to cheap labor, free trade, low taxes, high subsidies as well as due to ad-hoc protection of foreign investors from inefficient legal and administrative system (Arsić, et a.2019). 
According to the World Bank, the average level of domestic savings in Serbia in the period 2013 to 2017 was only $9.3 \%$ of GDP, while the average of CEE countries is $25.4 \%$ of GDP, and the Eurozone $24 \%$ of GDP. At the same time, the average of East Asian countries is around $34.4 \%$ of GDP. These data indicate that low domestic savings are one of the key causes of low domestic investment.

Low total investments negatively affect labor productivity, employment and future real wages, which encourages emigration trends. For the growth of total investments, it is necessary to increase productive public investments and, through economic policy, create systemic incentives for savings and investments. In the transition period, inadequate forms of foreign direct investment were represented in Serbia, which were realized mostly through privatization, and less through greenfield investments (Maksimović, Kostić, 2019).

Economic policy stimulates private investment if macroeconomic stability is maintained, embodied in low inflation, a stable exchange rate, low and relatively stable interest rates, and as long as there is no danger of a public or private debt crisis (Aizenman \& Nancy, 1993). Fatas \& Mihov (2003 and 2013) point out that the color for investment policy is that economic policy is conducted on the basis of permanent rules, rather than on the basis of government decisions.

For the Serbian economy, the connection between foreign direct investments and domestic small and medium enterprises is becoming increasingly important, in order to achieve the transfer of knowledge of foreign companies to domestic companies (Kovačević, 2019).

In a market economy, the state influences the level of private investment through income policy - if public sector wages grow faster than productivity, there is pressure to increase wages and increase labor costs in the private sector. In such situations, the return on private investment falls and investments begin to decline. In Serbia, frequent changes in economic policy are characteristic, and a large number of laws are adopted by urgent procedure, without the necessary public debate. This creates uncertainty in business and increases risk, so it negatively affects investment decisions.

Public investments in communal, energy and transport infrastructure reduce the operating costs of the private sector and have a positive effect on increasing investments. The level of investment in a country also depends on the structural characteristics of the economy and society, such as the development of the financial system, the openness of the economy, demographic characteristics and similar. The volume of credit activity of banks in Serbia lags behind the CEE countries by around $15 \%$ of GDP, while the lag in the development of other financial institutions is even higher (OECD, 2018). This refers to the insurance sector, private pension funds, the volume of stock trading, etc. For the small business sector, a serious limitation is the lack of a legal framework for the operation of non-banking financial organizations (microcredit organizations, etc.).

An important cause of low domestic investments in Serbia is weak institutions. They create the so-called non-commercial risks such as weak protection of property and contracts, frequent changes in regulations, etc. The characteristics of weak institutions are complicated bureaucratic procedures, high corruption, high gray economy, unequal treatment of investors and other. 
All this affects the increase in investment costs and, consequently, a smaller volume of investments. In such environment, investors are forced to spend a large part of their time and other resources on unproductive activities, such as lobbying, which results in a reduction of investment resources.

In such economic environment, according to Table 1, a trend of positive macroeconomic trends in Serbia has been achieved, despite the slowdown in the global economy. Economic activity is growing, and the main drivers of that growth are the inflow of foreign direct investment, the growth of exports and public and private consumption. The low inflation rate and the stable exchange rate were maintained, and the number of employees and the level of salaries increased.

Table 1: Basic macroeconomic indicators

\begin{tabular}{|l|r|r|}
\hline \multicolumn{1}{|c|}{ Description } & \multicolumn{2}{c|}{ Year } \\
\cline { 2 - 3 } & \multicolumn{1}{|c|}{2019} & \multicolumn{1}{c|}{2018} \\
\hline $\begin{array}{l}\text { Gross domestic product (inmiliions of dinars - current } \\
\text { prices) }\end{array}$ & $5.410 .794,3$ & $5.068 .588,5$ \\
\hline Gross domestic product's rate of growth & 4,2 & 4,4 \\
\hline Export (in millions of euros) & $17.533,4$ & $16.282,0$ \\
\hline Import (in millions of euros) & $23.875,1$ & $21.918,7$ \\
\hline Number of employees (in thousands) & 2.101 & 2.053 \\
\hline
\end{tabular}

Source: Serbian Business Registers Agency (2020)

There are structural problems in the Serbian economy, so the share of investments and exports in GDP is significantly lower than the average of Central and Eastern European (CEE) countries, and the share of private consumption is higher than in those countries. Similar relations are with the surrounding countries. The data in Table 2 show that further GDP growth cannot be based on an increase in consumption because it is already oversized in relation to production. The main drivers of economic growth must be investments and exports, and consumption must grow more slowly relative to GDP.

Table 2: Serbia and CEE: GDP's structure by consumption, average 2014-2017

\begin{tabular}{|l|c|c|c|c|c|}
\hline & $\begin{array}{l}\text { Personal } \\
\text { consumption }\end{array}$ & $\begin{array}{l}\text { Public } \\
\text { consumption }\end{array}$ & Investments & Export & Import \\
\hline & \multicolumn{5}{|c|}{ Participation in GDP } \\
\hline Serbia & 73,7 & 16,5 & 17,7 & 48,1 & 57,4 \\
\hline $\begin{array}{l}\text { CEE } \\
\text { (weighted } \\
\text { average }\end{array}$ & 57,8 & 17,7 & 21,2 & 60,9 & 58,6 \\
\hline $\begin{array}{l}\text { Surrounding } \\
\text { countries } \\
\text { (weighted } \\
\text { average) }\end{array}$ & 60,7 & 16,7 & 22,0 & 56,1 & 56,5 \\
\hline
\end{tabular}

Source: Eurostat, 2018. 


\section{Investment and development policy of an enterprise}

For a company that is preparing for the realization of a certain development project, questions are asked about the risks of certain investments and how much it will lead to an increase of the company's exposure to risk. Therefore, when considering the investment decision, the company is expected to identify and assess the risk, as well as to analyze the possibility of risk protection and risk control.

The basic characteristic of the investment process is that investing funds does not bring benefits immediately, but after a certain time. Investments are made in the present in order to achieve effects in the future that will be greater than the expenditures made. In order to maintain and survive in the dynamic conditions of the environment, the company is forced to invest in development. From the company's point of view, investments are the only way to achieve the goals of growth and development as well as maintaining and improving competitive advantage. They are a condition for the existence of the company, a condition that ensures its simple and extended reproduction.

The growth and development of an enterprise is not a goal for itself, but is aimed at enabling it to perform its mission in the existing environment as efficiently as possible. Rapid economic growth and technological progress have significantly increased investment opportunities for companies with limited financial resources. The development of the company is related to the correct choice and efficient realization of investments. Investments are part of the global development problem by which the company ensures its future existence and efficient functioning.

Development is not possible without investments because they are a precondition for its realization. Conversely, investments without properly defined development and adequate development policy, most often lead to failures and large losses. Development policy refers to determining the vision of enterprise development. It respects long-term goals in the form of business orientation, which serves as a prerequisite for establishing and choosing a growth strategy for the company.

The realization of the development policy and strategy of the company is mostly based on investments, investments are a way of realization of development, and the investment process is the final part of the development process that leads to immediate realization. In practice, the planning and implementation of enterprise development, in addition to defining the basic goals and directions of development, is mostly reduced to the definition and implementation of appropriate investment projects.

The growth and development of a company depends on a large number of factors. The growth of a company means a change in its size and is motivated by the desire to make higher profits, minimize costs, increase market share and similar. The sources of enterprise growth are contained in the market potential of existing products as well as in the potential of alternative markets for new products and services. The growth of the company was accompanied by a series of qualitative changes related to redefining the business strategy, redesigning the organizational structure, changing the way of management and other, which represent the development of the company, in order to ensure the efficiency and vitality of its business. 
Every company must understand the influence of environmental factors on its business. The environment inspires, but also punishes, so a complex analysis is necessary to identify the opportunities and dangers that the environment creates. The analysis determines the character, intensity and area of operation of the environment, which is the basis for the formation of the company's response strategy to opportunities and dangers. The framework in which strategic solutions for combining markets and products will be sought will also depend on the way of defining the position in relation to environmental factors.

Formulating a growth strategy, in addition to considering the factors of the external environment, requires knowledge of internal capabilities of the company. The ability to grow depends on creating an atmosphere of continuous learning and readiness for different and great challenges. A clear strategy for marketing, technology, production, human resources, finance and investment is needed. The formulation of the company's investment strategy provides guidelines for the realization of long-term development goals.

In formulating the investment strategy of the company, it is necessary to analyze the market environment and its factors, on the one hand, as well as internal capabilities and weaknesses, on the other hand. An integral part of each company's strategy is to determine the market determinants of its future appearance, such as market demand growth, profitability, economic, technological and socio-political turbulence, or its future competitive position (Ansoff, McDonnell, 1990).

The realization of the growth and development of the company takes place by initiating and implementing appropriate investment projects. Investing, as a process, continues the development planning process and within the overall development management process, includes one part of it. Therefore, from the development plan of the company, certain investment projects arise, the realization of which encourages the planned development. The investment program is done in the phase of planning and preparation of the realization of the investment, and on the basis of it investment decisions are made, which is a key moment in the preparation of the realization of the investment (Megginson, et al. 1983).

The negative consequences of wrong investment are reflected in the poor business results of the company. The consequence is a slight lag of the company in relation to the competition, as well as the loss of steps in technological development, which gradually leads to the loss of opportunities for the overall development of the company. The only way to stop and overcome these negative tendencies is to launch new, rational and profitable investments that will solve the existing delays in the development of the company.

Capital investments of a company represent a complete investment process. They refer to real goods that the company will use for the production of goods and services that will satisfy consumer demand. Capital investment decisions, such as the diversification of production or the introduction of significant innovations, can materially change the appearance of even large companies in a decade. They require large sums of money and can result in a large deviation from everything that and how the company did until then (Cvetković, 2002). 
The basic problem of investment decisionmaking comes down to the choice of the alternative that will, in conditions of limited funds, bring the greatest effects in terms of achieving the goals of economic and social development. Limited resources impose a narrower choice of investment alternatives that must be used efficiently, because every failure has long-term consequences for future development. The revival of investment in conditions of limited resources is a necessary factor to start the spiral: investment - production growth - a new round of investments.

The transition of the economy should ensure economically efficient business in the conditions of intense international competition and the application of innovative business and technical processes and trends. Company restructuring implies major changes aimed at achieving a better relationship with the environment and the interests of stakeholders. Therefore, its implementation must be based on methods and concepts of strategic management modeled on companies from developed market economies. Restructuring processes include a wide range of changes such as market, financial, ownership, organizational, technological, etc.

The domestic market belongs to the category of small and underdeveloped markets in which there are no conditions for propulsive business and enterprise development according to world standards. Therefore, it is necessary to redefine the target markets, create a supply structure in accordance with consumer requirements and adjust the strategy in order to gain and maintain a competitive advantage. The area through which long-term plans, development policy and strategy based on it are realized is the investment activity of the company. At the same time, investments in themselves do not provide effects, but represent a precondition for their actual realization.

The competitive position of a company is formulated in order to improve the existing position in the market in terms of increasing profitability or for fear of losing position in a dynamic business environment. Companies are exposed to competition from other companies, but government intervention measures can also significantly affect their position. The fight for a larger market share is led by reducing costs, increasing sales volumes, through competitive prices and diversification of supply.

The basic strategic dilemma in formulating a growth strategy is how to harmonize the directions and methods of growth so that they correspond to the state of the economy and the level of development of a particular company. Ensuring growth is possible by applying a strategy of expansion and diversification. These growth directions are based on an appropriate combination of products and markets. Enterprise growth can be focused on activating sources of profit within different combinations of markets and products, where the two dominant directions of growth are known as expansion and diversification.

On the other hand, it is possible to identify factors that may act in the direction of limiting or eliminating the investment activity of companies which include declining market needs, the existence of competition that creates large or insurmountable barriers to entry in a particular area of business to which they belong, starting from technological dominance, through advantages in obtaining loans, to more favorable access to some inelastic distribution channels. 
Legislation, reduced opportunities for procurement of material resources, limited conditions for obtaining financial resources, underdeveloped infrastructure or disincentives for the community, ie the country's economic policy, should also be included (Todorović, et al, 1997).

\section{Conclusion}

The Serbian economy in the transition period recorded low growth rates, which leads to a further lag behind comparable countries in Central and Eastern Europe. One of the important causes of such trends is significantly lower public and private investments in Serbia compared to these countries. On the other hand, relatively high foreign direct investment did not lead to a significant economic rise or a reduction in the development gap. Based on this, a logical conclusion is drawn that economic development cannot be based only on foreign investments but on their cooperation with domestic public and private investments, based on domestic savings. In order to achieve such development effects, it is necessary to create a better investment environment through economic policy, which would stimulate an increased share of investments in the gross domestic product.

\section{References}

Agencija za privredne registre, (2020), Godišnji izveštaj o poslovanju privrede u 2019. godini, Beograd
Aizenman, J., Nancy, M., (1993) Policy Uncertainty, Persistence and Growth, Review of International Economics 1:145-63

Ansoff, I., McDonnell, E, (1990), Implanting Strategic Management, Prentice - Hall, New York

Arsić, M., Ranđelović, S., Nojković, A., (2019) Causes and consequences of low investments in Serbia, Zbornik radova Ekonomska politika Srbije u 2019. godini, Naučno društvo ekonomista Srbije, SANU i Ekonomski fakultet Beograd, str. 43-61.

Cvetković, N., (2002) Strategija investicija preduzeća, Institut ekonomskih nauka, Beograd

Fatas, A., Mihov, I., (2013), „Policy Volatility, Institutions, and Economic Growth", The Review of Economics and Statistics 95(2): 362-376.

Kovačević, R., (2019), „Uticaj stranih direktnih investicija na izvozne performanse i platni bilans Srbije“, Zbornik radova Ekonomska politika Srbije u 2019. godini, Naučno društvo ekonomista Srbije, SANU i Ekonomski fakultet Beograd, str. 111126.

Maksimović, Lj., Kostić, M., (2019), „Dinamika i implikacije odnosa stranih direktnih investicija i tekućeg bilansa odabranih zemalja Balkana“, Zbornik radova Ekonomska politika Srbije u 2019. godini, Naučno društvo ekonomista Srbije, SANU i Ekonomski fakultet Beograd, str. 61-74.

Megginson, L., Mosley, D., Pietri, P., (1983) Management, Conteps and Aplications, Harper\& Row, New York

Todorović, J., Đuričin, D., Janošević, S. (1997) Strategijski menadžment, Institut za tržišna istraživanja, Beograd 